\title{
PENGARUH MODEL KOOPERATIF TIPE NHT TERHADAP HASIL BELAJAR SISWA KELAS VIII SMP NEGERI 18 MEDAN
}

\author{
Faridah Anum Siregar \\ Jurusan Pendidikan Fisika \\ Program Pascasarjana Universitas Negeri Medan
}

\begin{abstract}
Abstrak. Penelitian ini bertujuan untuk mengetahui pengaruh model Kooperatif Tipe NHT terhadap hasil belajar siswa semester genap pada sub materi pokok Tekanan Pada Zat Padat dan Zat Cair di SMP Negeri 18 Medan T.P 2009/2010. Jenis penelitian ini adalah eksperimen two group pretest postest. Populasi dalam penelitian adalah seluruh siswa kelas VIII Semester Genap SMP Negeri 18 Medan yang terdiri dari 8 kelas berjumlah 320 orang. Pengambilan sampel dilakukan dengan cara cluster random sampling yaitu dengan mengambil 2 kelas dari 8 kelas secara acak. Dari hasil uji t-test diperoleh $t_{\text {hitung }}$ sebesar 2,458 dengan probabilitas $0,017<0,05$. Ini berarti ada pengaruh yang signifikan penggunaan model kooperatif tipe NHT terhadap hasil belajar siswa pada sub materi pokok Tekanan Pada Zat Padat dan Zat Cair Semester Genap SMP Negeri 18 Medan T.P 2009/2010.
\end{abstract}

\section{Kata kunci: model pembelajaran, NHT, hasil belajar}

\section{Pendahuluan}

Pendidikan merupakan kebutuhan sepanjang hayat, setiap manusia membutuhkan pendidikan sampai kapan dan dimanapun ia berada. Pendidikan sangat penting artinya, sebab tanpa pendidikan manusia akan sulit berkembang dan bahkan akan terbelakang. Berkembangnya pendidikan sudah pasti berpengaruh terhadap perkembangan Ilmu Pengetahuan dan Teknologi dan tidak dapat terlepas dari kemajuan ilmu Fisika yang banyak menghasilkan temuan baru dalam bidang sains dan teknologi tersebut. Oleh karena itu, Fisika ditempatkan sebagai salah satu mata pelajaran yang penting.

Tetapi upaya tersebut belum mampu meningkatkan mutu hasil pembelajaran yang berarti. Salah satu penyebabnya adalah rendahnya mutu hasil belajar siswa, khususnya pada mata pelajaran IPA/sains. Hal ini dapat dibuktikan dari hasil studi pendahuluan yang telah dilakukan peneliti di SMPN I8 Medan, hasilhasil evaluasi belajar menunjukkan bahwa nilai rata-rata kelas di rapor untuk pelajaran Fisika tergolong masih rendah dalam kategori cukup yaitu dengan nilai rata-rata 71 , dengan KKM 70. Rendahnya hasil belajar siswa tersebut disebabkan beberapa faktor antara lain karena masih banyak siswa yang tidak menyukai pelajaran Fisika. Hal ini dibuktikan dari hasil angket yang diberikan kepada 40 orang siswa kelas VIII, sebanyak 62\% (25 orang siswa) menganggap Fisika itu adalah pelajaran yang sulit, memiliki banyak rumus, kurang menarik, tidak menyenangkan, dan susah dalam mengerjakan soal-soalnya, karena selain melibatkan perhitungan juga melibatkan kejadian alam, $27 \%$ (11 orang siswa) berpendapat Fisika biasabiasa saja, dan hanya $10 \%$ (4 orang siswa) yang berpendapat Fisika menyenangkan dan menantang. Dari hasil wawancara dengan Ibu Dra. T. Siahaan selaku guru Fisika kelas VIII di SMP Negeri 18 Medan dapat disimpulkan bahwa masih kurangnya penggunaan variasi model pembelajaran, yang pada umumnya hanya menggunakan pembelajaran konvensional yang hanya didominasi oleh metode ceramah dan jarangnya digunakan media pembelajaran yang dapat memperjelas gambaran siswa tentang 
materi yang dipelajari karena keterbatasan alat dan ruangan laboratorium.

Langkah perbaikan dalam pembelajaran yang dapat dilakukan salah satunya adalah dengan memilih model pembelajaran yang tepat, yaitu model pembelajaran kooperatif. Banyak tipe model kooperatif yang dapat digunakan, antara lain model pembelajaran kooperatif tipe NHT (Numbered Head Together). NHT merupakan salah satu tipe dari model pembelajaran kooperatif, yang melibatkan para siswa dalam melihat kembali bahan yang tercakup dalam suatu pembelajaran dan memeriksa pemahaman siswa mengenai isi pelajaran tersebut (Nurhadi, 2004).

Berdasarkan uraian latar belakang masalah diatas, maka dapat diidentifikasikan beberapa masalah, yaitu: (1) Fisika merupakan pelajaran yang terkesan sulit, kurang menarik, dan kurang menyenangkan untuk dipahami dikalangan siswa. (2) Kurangnya penggunaan model dan media secara efektif dalam pembelajaran yang pada umumnya hanya didominasi dengan pembelajaran konvensional. Adapun batasan masalahnya: (1) Model pembelajaran yang digunakan adalah model kooperatif tipe NHT. (2) Media pembelajaran yang digunakan adalah media praktikum sederhana. (3) Subjek penelitian adalah siswa kelas VIII semester genap SMPN 18 Medan T. P 2009/2010. (4) Materi pokok yang dibahas dalam penelitian ini adalah materi Tekanan dan dibatasi hanya pada sub materi Tekanan Pada Zat Padat dan Zat Cair.

Berdasarkan latar belakang masalah dan batasan masalah diatas maka rumusan masalah pada penelitian ini adalah (1) Bagaimana hasil belajar Fisika siswa sebelum dan sesudah menggunakan model kooperatif tipe NHT pada materi pokok Tekanan pada sub materi Tekanan Pada Zat Padat dan Zat Cair di kelas VIII semester genap SMPN 18 Medan TP. 2009/ 2010? (2) Bagaimana hasil belajar Fisika siswa yang tidak menggunakan model kooperatif tipe NHT pada materi pokok Tekanan pada sub materi Tekanan Pada Zat Padat dan Zat Cair di kelas VIII semester genap SMPN 18 Medan TP. 2009/2010? (3) Bagaimana aktivitas belajar siswa yang menggunakan model kooperatif tipe NHT terhadap hasil belajar Fisika siswa pada materi pokok Tekanan pada sub materi Tekanan Pada Zat Cair di kelas VIII semester genap SMPN 18 Medan TP. 2009/2010? (4) Apakah ada pengaruh model kooperatif tipe NHT terhadap hasil belajar Fisika siswa pada materi pokok Tekanan pada sub materi Tekanan Pada Zat Cair di kelas VIII semester genap SMPN 18 Medan TP. 2009/2010?

Sejalan dengan perumusan masalah di atas, maka tujuan penelitian ini adalah untuk (1) Mengetahui hasil belajar Fisika siswa sebelum dan sesudah menggunakan model kooperatif tipe NHT pada materi pokok Tekanan pada sub materi Tekanan Pada Zat Padat dan Zat Cair di kelas VIII semester genap SMPN 18 Medan TP. 2009/2010. (2) Mengetahui hasil belajar Fisika siswa yang tidak menggunakan model kooperatif tipe NHT pada materi pokok Tekanan pada sub materi Tekanan Pada Zat Padat dan Zat Cair di kelas VIII semester genap SMPN 18 Medan TP. 2009/ 2010. (3) Mengetahui aktivitas belajar siswa yang menggunakan model kooperatif tipe NHT terhadap hasil belajar Fisika siswa pada materi pokok Tekanan pada sub materi Tekanan Pada Zat Padat dan Zat Cair di kelas VIII semester genap SMPN 18 Medan TP. 2009/2010. (4) Mengetahui pengaruh model kooperatif tipe NHT terhadap hasil belajar Fisika siswa pada materi pokok Tekanan pada sub materi Tekanan Pada Zat Padat dan Zat Cair di kelas VIII semester genap SMPN 18 Medan TP. 2009/2010.

\section{Pembelajaran Konvensional}

Menurut Djamarah (1996) pembelajaran konvensional adalah pembelajaran tradisional atau disebut juga dengan metode ceramah, karena sejak dulu pembelajaran ini telah dipergunakan sebagai alat komunikasi lisan antara guru dengan anak didik dalam proses belajar dan pembelajaran. Dalam pembelajaran konvensional ditandai dengan ceramah yang diiringi dengan penjelasan, serta pembagian tugas dan latihan. Selanjutnya menurut Roestiyah (1998) cara mengajar yang paling tradisional dan telah 
lama dijalankan dalam sejarah pendidikan ialah cara mengajar dengan ceramah. Sejak duhulu guru dalam usaha menyampaikan pengetahuannya pada siswa ialah secara lisan atau ceramah. Pembelajaran konvensional yang dimaksud adalah pembelajaran yang biasa dilakukan oleh para guru.

Dari uraian di atas, dapat diambil suatu kesimpulan bahwa yang dimaksud dengan pembelajaran Fisika secara konvensional adalah suatu kegiatan belajar mengajar yang selama ini kebanyakan dilakukan oleh guru dimana guru mengajar secara klasikal yang di dalamnya aktivitas guru mendominasi kelas dan siswa hanya menerima apa-apa saja yang disampaikan oleh guru, begitupun aktivitas siswa untuk menyampaikan pendapat sangat kurang, sehingga siswa menjadi pasif dalam belajar, dan belajar siswa kurang bermakna karena lebih banyak berupa hapalan.

\section{Aktivitas Belajar}

Didalam belajar diperlukan aktivitas, sebab pada prinsipnya belajar adalah berbuat, berbuat untuk mengubah tingkah laku. Tidak ada belajar kalau tidak ada aktivitas. Itulah sebabnya aktivitas merupakan prinsip atau asas yang sangat penting didalam interaksi belajar mengajar. Dalam kegiatan belajar mengajar, guru dan anak didik terlibat dalam sebuah interaksi dengan bahan pelajaran sebagai medianya. Dalam interaksi itu anak didiklah yang lebih aktif, bukan guru. Guru hanya berperan sebagai motivator dan fasilitator (Djamarah dan Zain, 2006).

\section{Hasil Belajar}

Hasil belajar adalah kemampuan yang dimiliki siswa setelah ia menerima pengalaman belajarnya. Hasil belajar mempunyai peranan penting dalam proses pembelajaran. Proses penilaian terhadap hasil belajar dapat memberikan informasi kepada guru tentang kemajuan siswa dalam upaya mencapai tujuan-tujuan belajarnya melalui kegiatan belajar. Selanjutnya dari informasi tersebut guru dapat menyusun dan membina kegiatan-kegiatan siswa lebih lanjut, baik untuk keseluruhan kelas maupun individu. Hasil belajar yang diperoleh siswa adalah sebagai akibat dari proses belajar yang dilakukan oleh siswa, harus semakin tinggi hasil belajar yang diperoleh siswa. Proses belajar merupakan penunjang hasil belajar yang dicapai siswa. Dengan berakhirnya belajar maka siswa memperoleh suatu hasil belajar. Hasil belajar merupakan hasil dari suatu interaksi tindak belajar dan tindak mengajar. Dari sisi guru, tindak mengajar diakhiri dengan proses evaluasi hasil belajar. Dari sisi siswa, hasil belajar merupakan berakhirnya penggal dan puncak proses belajar (Dimyati dan Mudjiono, 2006)

\section{Pembelajaran Kooperatif Tipe NHT}

Pembelajaran kooperatif tipe NHT merupakan salah satu tipe pembelajaran kooperatif yang menekankan pada struktur khusus yang dirancang untuk mempengaruhi pola interaksi siswa dan memiliki tujuan untuk meningkatkan penguasaan akademik. Tipe ini dikembangkan oleh Kagen dalam Ibrahim (2000) dengan melibatkan para siswa dalam menelaah materi yang tercakup dalam suatu pelajaran dan mengecek pemahaman mereka terhadap isi pelajaran tersebut.

Untuk mengajukan pertanyaan kepada seluruh kelas, guru menggunakan empat langkah sebagai berikut:

1. Langkah 1: Penomoran (Numbering). Guru membagi para siswa menjadi beberapa kelompok atau tim yang beranggotakan 3 hingga 5 orang dan memberi mereka nomor sehingga tiap siswa dalam tim memiliki nomor berbeda.

2. Langkah 2: Pengajuan Pertanyaan (Questioning). Guru mengajukan pertanyaan kepada para siswa. Pertanyaan dapat bervariasi, dari yang bersifat spesifik hingga yang bersifat umum.

3. Langkah 3: Berpikir Bersama (Head Together). Para siswa berpikir bersama untuk menggambarkan dan meyakinkan bahwa tiap orang mengetahui jawaban tersebut. 
4. Langkah 4: Pemberian Jawaban (Answering). Guru menyebut satu nomor dan para siswa dari tiap kelompok dengan nomor yang sama mengangkat tangan dan menyiapkan jawaban untuk seluruh kelas (Nurhadi, 2004).

\section{Metode Penelitian}

Penelitian ini dilaksanakan di SMPN 18 Medan Jl. Kemuning Raya Perumnas Helvetia pada semester genap T.P 2009/2010. Populasi dalam penelitian ini adalah seluruh siswa kelas VIII SMPN 18 Medan yang terdiri dari 8 kelas berjumlah 320 siswa. Sampel penelitian diambil secara cluster random sampling yaitu dengan mengambil 2 kelas dari 8 kelas secara acak. Kedua kelas masing-masing berjumlah 35 orang yang mewakili populasi dengan karakteristik sama, yaitu kelas eksperimen yang menggunakan model kooperatif tipe NHT dan kelas kontrol yang tidak menggunakan model kooperatif tipe NHT. Penelitian ini termasuk jenis penelitian eksperimen yaitu merupakan penelitian yang dimaksudkan untuk mengetahui ada tidaknya akibat dari sesuatu yang dikenakan pada sampel yaitu siswa.

Tabel 1. Desain Penelitian Two Group Pretest Postest

\begin{tabular}{|l|c|c|c|}
\hline \multicolumn{1}{|c|}{ Sampel } & Pre-test & Perlakuan & Post-test \\
\hline Kelas Eksperimen & $\mathrm{T}_{1}$ & $\mathrm{X}$ & $\mathrm{T}_{2}$ \\
\hline Kelas Kontrol & $\mathrm{T}_{1}$ & $\mathrm{O}$ & $\mathrm{T}_{2}$ \\
\hline
\end{tabular}

Keterangan:

$\mathrm{X}=$ Pembelajaran dengan menggunakan model kooperatif tipe NHT dengan media praktikum sederhana.

$\mathrm{O}=$ Pembelajaran dengan menggunakan model kooperatif tipe NHT tidak dengan media praktikum sederhana.

$\mathrm{T}_{1}=$ Pre test diberikan sebelum perlakuan kepada kelas eksperimen dan kelas kontrol.

$\mathrm{T}_{2}=$ Post test diberikan setelah perlakuan kepada kelas eksperimen dan kelas kontrol.

Bila data penelitian berdistribusi normal dan homogen maka untuk menguji hipotesis apakah sebenarnya diterima atau ditolak diguna- kan uji t pada taraf signifikan $\alpha=0,05$, dengan derajat kebebasan $\mathrm{dk}=\mathrm{n}_{1}+\mathrm{n}_{2}-2$.

$$
t=\frac{x_{1}-\overline{x_{2}}}{s \sqrt{\frac{1}{n_{1}}+\frac{1}{n_{2}}}}(\text { Sudjana, 2005) }
$$

$s^{2}=\frac{\left(n_{1}-1\right) s_{1}^{2}+\left(n_{2}-2\right) s_{2}^{2}}{n_{1}+n_{2}-2}$ (Sudjana, 2005)

Keterangan:

$t_{\text {hitung }}=$ Harga $\mathrm{t}$ perhitungan; $\overline{X_{1}}=$ Nilai ratarata hasil belajar siswa kelas eksperimen; $\overline{X_{2}}=$ Nilai rata-rata hasil belajar siswa kelas control; $n_{1}=$ Jumlah sampel kelas eksperimen; $n_{2}=$ Jumlah sampel kelas kontrol; $S^{2}=$ Varians hasil belajar gabungan dua kelas; $S_{1}^{2}=$ Varians hasil belajar pada kelas eksperimen; $S_{2}^{2}=$ Varians hasil belajar pada kelas kontrol.

Selanjutnya mencari harga t pada tabel (ttes) pada tingkat kepercayaan 5\%. Kriteria pengujian adalah terima $\mathrm{H}_{\mathrm{o}}$ jika $-\mathrm{t}_{1-1 / 2} \alpha<\mathrm{t}_{\mathrm{h}}<\mathrm{t}_{1-}$ $1 / 2 \alpha$, dimana $t_{1-1 / 2} \alpha$ didapat dari daftar distribusi t dengan $\mathrm{dk}=\left(\mathrm{n}_{1}+\mathrm{n}_{2}-2\right)$ dan peluang $(1-1 / 2 \alpha)$. Untuk harga-harga $t$ lainnya $H_{o}$ ditolak.

\section{Hasil Penelitian dan Pembahasan}

Pada awal penelitian kedua kelas diberikan tes uji kemampuan awal (pretes) yang bertujuan untuk mengetahui apakah kemampuan awal siswa pada kedua kelompok kelas sama atau tidak. Berdasarkan data hasil penelitian pada lampiran diperoleh nilai rata-rata pretes siswa pada kelas eksperimen sebelum diberi perlakuan dengan menggunakan model pembelajaran kooperatif tipe NHT 31,6 dengan standar deviasi 8,6 dan nilai rata-rata pretes kelas kontrol 30,8 dengan standar deviasi 8,9.

Berdasarkan hasil perhitungan menggunakan SPSS 16.0 diperoleh nilai Asymp. Sig. (2-tailed) sebesar 0,807 atau lebih besar dari signifikansi yang diterapkan yaitu 0,05 . Ini berarti data skor pretes kedua kelas sebelum diberikan perlakuan yang berbeda dinyatakan 
berdistribusi normal dengan ukuran normal rata-rata 31,21 dan standar deviasi 8,7 serta nilai mutlak dari perbedaan yang paling ekstrim sebesar 0,77 .

Hasil perhitungan menggunakan SPSS 16.0 berdasarkan analisis levene's Test diperoleh $F_{\text {hitung }} 0,214$ dengan probabilitas 0,645 $>0,05$ maka disimpulkan bahwa kedua data pretes siswa baik kelas eksperimen maupun kelas kontrol memiliki varians populasi yang sama (homogen). Maka dengan kata lain bahwa kemampuan awal siswa pada kelas eksperimen sama dengan kemampuan awal siswa pada kelas kontrol terhadap hasil belajar Fisika siswa pada materi pokok Tekanan pada sub materi Tekanan Pada Zat Padat dan Zat Cair kelas VIII SMPN 18 Medan TP. 2009/2010.

Setelah kedua kelas diberikan perlakuan yang berbeda, kedua kelas selanjutnya diberikan postes dengan soal yang sama seperti soal pretes. Hasil yang diperoleh adalah, nilai ratarata postes kelas eksperimen setelah diterapkan model pembelajaran kooperatif tipe NHT 77,4 dengan standar deviasi 11,9. Sedangkan pada kelas kontrol setelah diterapkan pembelajaran konvensional diperoleh nilai rata-rata postes 69,9 dengan standar deviasi 13,3.

Setelah memperoleh data hasil postes siswa dari kedua kelas, untuk mengetahui apakah data postes kedua kelas memiliki penyebaran data postes yang berdistribusi normal maka dilakukan pengujian normalitas data postes. Berdasarkan hasil perhitungan dengan menggunakan SPSS 16.0 diperoleh nilai Asymp. Sig. (2-tailed) sebesar 0,122 atau lebih besar dari signifikansi yang diterapkan yaitu 0,05. Ini berarti bahwa data skor postes kedua kelas setelah diberikan perlakuan yang berbeda dinyatakan berdistribusi normal dengan ukuran normal rata-rata 73,643 dan standar deviasi 13,096 serta nilai mutlak dari perbedaan yang paling ekstrim sebesar 0,141 .

Setelah diperoleh bahwa penyebaran data postes kedua kelompok berdistribusi normal selanjutnya dilakukan uji homogenitas dan uji beda yang bertujuan untuk mengetahui kesamaan antara nilai postes di kelas eksperimen dan kontrol dengan menggunakan analisis statistik Independent Samples Test. Hasil pengujian dengan menggunakan SPSS 16.0 yang hasilnya menunjukkan bahwa berdasarkan analisis levene's Test diperoleh $F_{\text {hitung }}$ 0,756 dengan probabilitas $0,388>0,05$ maka disimpulkan bahwa kedua data postes siswa baik kelas eksperimen maupun kelas kontrol memiliki varians populasi yang sama. Berdasarkan analisis t-test untuk equal variances assumed diperoleh $\mathrm{t}_{\text {hitung }}$ sebesar 2,458 dengan probabilitas $0,017<$ 0,05 sehingga dapat disimpulkan bahwa terdapat perbedaan yang signifikan antara hasil belajar siswa yang menggunakan model pembelajaran kooperatif tipe NHT dibandingkan dengan hasil belajar siswa yang menggunakan model pembelajaran konvensional pada materi pokok Tekanan di Kelas VIII Semester Genap SMP Negeri 18 Medan T.P 2009/2010.

Hasil pengujian hipotesis diperoleh $\mathrm{H}_{\mathrm{a}}$ diterima dan $\mathrm{H}_{\mathrm{o}}$ ditolak, artinya Terdapat pengaruh model kooperatif tipe NHT terhadap hasil belajar Fisika siswa pada materi pokok Tekanan di kelas VIII SMPN 18 Medan T.P 2009/2010.

Untuk mengamati aktivitas belajar siswa selama pembelajaran dengan model kooperatif tipe NHT dilakukan observasi. Observasi ini dilakukan oleh tiga orang pengamat/observer yaitu satu orang guru bidang studi dan dua orang teman sejawat peneliti selama kegiatan belajar mengajar yang terdiri dari tiga kali pertemuan. Pada saat observer mengamati aktivitas belajar siswa dalam pembelajaran, yang diamati adalah persentase keaktifan siswa, kemudian digolongkan pada kriteria baik, cukup dan kurang. Dalam satu kelas peneliti mengambil 35 siswa untuk menjadi sampel aktivitas siswa yang dibagi menjadi tujuh kelompok. Hasil observasi diketahui bahwa aktivitas belajar siswa dari pertemuan I sampai pertemuan III di kelas eksperimen mengalami peningkatan selama menerima pembelajaran dengan menggunakan model pembelajaran kooperatif tipe NHT yaitu peningkatan aktivitas belajar siswa dengan rata-rata nilai pertemuan I 57,85 (Kurang), pertemuan II 67,15 (Cukup), dan 
pertemuan III 76,96 (Baik). Ini menunjukkan bahwa model pembelajaran kooperatif tipe NHT tidak hanya meningkatkan hasil belajar saja, tetapi mampu meningkatkan aktivitas siswa.

\section{Pembahasan}

Hasil penelitian menunjukkan bahwa ada pengaruh yang signifikan menggunakan model pembelajaran kooperatif tipe NHT (Numbered Heads Together) terhadap hasil belajar siswa pada sub materi Tekanan Pada Zat Padat dan Zat Cair di Kelas VIII Semester II SMP Negeri 18 Medan T.P 2009/2010. Hal ini ditunjukkan dengan perolehan nilai rata-rata postes di kelas eksperimen sebesar 77,4 dengan standar deviasi 11,9. Sedangkan di kelas kontrol diperoleh nilai rata-rata postes sebesar 69,9 dengan standar deviasi 13,3 . Artinya terdapat perbedaan ratarata nilai postes antara kelas eksperimen dan kelas kontrol sebesar 7,5 atau sebesar 10,7\%.

Hal ini dikarenakan pembelajaran dengan model kooperatif tipe NHT pada kelas eksperimen memberikan banyak keuntungan yaitu (1) Pada langkah Penomoran (Numbering) siswa dalam anggota kelompok diberi nomor yang berbeda, sehingga siswa menjadi lebih bertanggungjawab terhadap tugas yang diberikan. (2) Pada langkah Berpikir Bersama (Head Together) siswa lebih terarah dalam menyelesaikan tugas yang diberikan, karena langkah ini dapat menjadi wadah bagi siswa dalam bekerjasama untuk mencapai tujuan pembelajaran dalam menyelesaikan tugas-tugas akademik seperti menjawab soal-soal mengenai materi dari guru. (3) Pada langkah Pengajuan Pertanyaan (Questioning) dan Pemberian Jawaban (Answering), menjadikan setiap anggota kelompok akan saling membantu demi keberhasilan dan nama baik kelompok.

Selain dapat meningkatkaan hasil belajar siswa, model pembelajaran kooperatif tipe NHT ternyata juga dapat meningkatkan aktivitas belajar siswa. Hal ini ditunjukkan dari hasil pengamatan yang dilakukan oleh observer, diperoleh bahwa aktivitas siswa mengalami peningkatan yang positif.

\section{Simpulan}

Berdasarkan hasil penelitian yang diperoleh dari hasil analisa data dan pengujian hipotesis maka dapat disimpulkan: (1) Hasil belajar Fisika siswa sebelum menggunakan model pembelajaran kooperatif tipe NHT pada materi pokok Tekanan pada sub materi pokok Tekanan pada Zat Padat dan Zat Cair adalah sebesar 31,6 dan sesudah menggunakan model pembelajaran kooperatif tipe NHT pada materi pokok Tekanan pada sub materi pokok Tekanan pada Zat Padat dan Zat Cair adalah sebesar 77,4. (2) Hasil belajar Fisika siswa yang tidak menggunakan model pembelajaran kooperatif tipe NHT pada materi pokok Tekanan pada sub materi pokok Tekanan pada Zat Padat dan Zat Cair adalah sebesar 69,9. (3) Aktivitas belajar siswa yang diamati pada pembelajaran kooperatif tipe NHT mengalami peningkatan dari pertemuan I sebesar $57,85 \%$ sampai pertemuan III sebesar 76, 96\%. Aktivitas siswa yang dikategorikan baik sejalan dengan peningkatan hasil belajar siswa yang juga dikategorikan baik yaitu 77,4 sehingga aktivitas siswa memiliki pengaruh positif terhadap hasil belajar. (4) Ada pengaruh yang signifikan menggunakan model pembalajaran kooperatif tipe NHT terhadap hasil belajar siswa pada materi pokok Tekanan pada sub materi pokok Tekanan pada Zat Padat dan Zat Cair Kelas VIII Semester Genap SMP Negeri 18 Medan T.P. 2009/2010.

\section{Daftar Pustaka}

Dimyati dan Mudjiono. 2002. Belajar dan Pembelajaran. Jakarta: Rineka Cipta.

Djamarah, S. dan Zain. A. 2006. Strategi Belajar Mengajar. Jakarta: Rineka Cipta.

Ibrahim, M. 200. Belajar Kooperatif. Surabaya: Unes.

Roestiyah, N. 1998. Strategi Belajar Mengajar. Jakarta: Rineka Cipta.

Nurhadi. 2004. Kurikulum 2004 Pertanyaan dan Jawaban. Jakarta: Grasindo.

Sudjana. 2005). Metode Statistika. Bandung: Tarsito. 